Sains Malaysiana 49(12)(2020): 3179-3188

http://dx.doi.org/10.17576/jsm-2020-4912-29

\title{
Effects of the Synthesis Coating Parameters for Metal Bipolar Plates
}

(Kesan Parameter Salutan Sintesis untuk Plat Dwikutub Logam)

\author{
Nur Fawwaz Asri, Teuku Husaini*, Abu BaKar Sulong \& Edy Herianto Majlan
}

\begin{abstract}
Metallic bipolar plates tendency to have high contact resistance, but also very susceptible to corrosion. This may decrease in the performance of fuel cells after several times of usage in fuel cell applications. Research has shown that after a metal plate was coated, the characteristic of materials dependent on the type, composition of the coating materials and the method. This study determines design of coating parameters including gas flow rate, DC power, and deposition time of coating for metal bipolar plates, which can be an indicator of the suitability of these plates for use as bipolar plates in proton exchange membrane fuel cell (PEMFC) applications. The aim of this research was to obtain a limitation range value of parameters that can be used as a standard for the use of metal plates as bipolar plates. The optimization parameters designed by Taguchi are used to determine the characteristics of interfacial contact resistance (ICR) and corrosion current density $\left(I_{\text {corr }}\right)$. The integration of the Taguchi method with simulation can show the optimal design parameters of the coating on the various materials use. The optimization feature based on Taguchi is applied to ICR and $I_{\text {corr }}$ values, to determine the feasibility of metal plates as potential bipolar plates in PEMFC.
\end{abstract}

Keywords: Coating bipolar plate; $\mathrm{Cr}-\mathrm{C}$; metallic bipolar plates; $\mathrm{Nb}-\mathrm{C}$; Taguchi

ABSTRAK

Kecenderungan plat dwikutub logam mempunyai rintangan sentuh dan kadar kakisan tinggi, namun mudah terdedah kepada kakisan. Penyelidikan ini telah menunjukkan bahawa setelah plat logam disalut, sifat elektrik dipengaruhi oleh jenis dan komposisi salutan yang digunakan, dan kaedah rawatan salutan yang dijalankan. Kajian ini menentukan parameter salutan merangkumi kadar aliran gas, kuasa DC dan masa pemendapan lapisan untuk plat dwikutub logam, untuk mencapai kesesuaian plat digunakan sebagai plat dwikutub dalam aplikasi PEMFC. Pengoptimuman melalui Taguchi dapat digunakan sebagai penentuan pencirian rintangan sentuh antara muka (ICR) dan ketumpatan arus kakisan $\left(I_{c o r}\right)$. Fokus kajian terhadap kesinambungan kaedah Taguchi dan simulasi menunjukkan reka bentuk parameter optimum salutan $\mathrm{Nb}-\mathrm{C}$ dan $\mathrm{Cr}-\mathrm{C}$. Penyatuan kaedah Taguchi dengan simulasi rintangan kakisan dan ICR dapat menunjukkan parameter reka bentuk salutan yang optimum pada pelbagai bahan yang digunakan. Ciri pengoptimuman berdasarkan Taguchi diterapkan pada nilai ICR dan $I_{\text {corr, }}$, untuk menentukan kemungkinan plat logam sebagai plat dwikutub berpotensi dalam PEMFC.

Kata kunci: Cr-C; $N b-C$; plat dwikutub logam; plat dwikutub salutan; Taguchi

\section{INTRODUCTION}

Metallic bipolar plates tendency to have high contact resistance and corrosion rate after several times of usage in proton exchange membrane fuel cell (PEMFC) conditions, that affected performance of a cell in PEMFC stack. High electrical conductivity, good corrosion resistance, thin and lightweight are bipolar plates characteristics in PEMFC (Baroutaji et al. 2015). Few years of difficulty in making bipolar plates by many researcher using graphite materials, that was brittle especially in manufactured graphite flow field channels (Hartnig et al. 2011). To keep alligned with current fuel cell technologies in terms of cost as well as high efficiency, metallic bipolar plates were introduced to improve PEMFC performance. Metal such as carbon steel, titanium, and stainless steel were an alternative material for metallic bipolar plates 
that can survive within the PEMFC (Mani \& Rajendran 2017). However, the corrosion resistance of metal bipolar plates will be reduced for a certain period which leads to decrease in the performance of bipolar plates (Li et al. 2018). Therefore, surface treatment was performed for related problems (Madadi et al. 2019).

The bipolar plate manufacturing needs to achieve the standard set by U.S. Department of Energy (DOE) (Taherian 2014). For metal bipolar plates, the important target value is to achieve electrical conductivity up to $100 \mathrm{~S} / \mathrm{cm}$ and corrosion current density is $<1 \mu \mathrm{A} / \mathrm{cm}^{2}$. Extensive studies of researchers on the application of bipolar plates are also conducted to obtain good conductivity and mechanical properties aligned with U.S. DOE targets. Huang et al. (2016) studied $\mathrm{Cr}-\mathrm{C}$ is the ideal coating material on $316 \mathrm{~L}$ stainless steel because it gives corrosion current density up to $0.04 \mu \mathrm{A} \mathrm{cm}^{-2}$ with low ICR value of $4.27 \mathrm{~m} \Omega \mathrm{cm}^{2}$. In addition, good chemical stability of protective layer on stainless steel bipolar plates for up to 30 days in potentiostatic polarization gives low corrosion density current up to $0.13 \mu \mathrm{A} \mathrm{cm} \mathrm{cm}^{-2}$, by using niobium $(\mathrm{Nb})$ deposited of $\mathrm{TiO}_{2}$ through sol-gel techniques (Wang et al. 2018). Therefore, stainless steel can reduce the machining process to form into thin sheets, corrosion resistance and high material strength, as well as low price to be considered a good material candidate for metallic bipolar plate in PEMFC (Wang et al. 2003). Hence, these types of metal are superior with the high content of weight percentages of $\mathrm{Cr}$ and $\mathrm{Ni}$, hence increase electrical conductivity as well in the PEMFC (Arwati et al. 2019). Herewith, the study showed that metal plated promise a choice with a variety of power into becoming bipolar plate in PEMFC applications (Yang et al. 2017).

The study also used Taguchi method for optimization of coating parameter using PVD to obtain suitable coating formation parameters on SUS $316 \mathrm{~L}$ substrate. In between, screening of coating parameters produced on SUS $316 \mathrm{~L}$ plates will go through a series of tests, to ensure the substrate after coatings produced meet U.S. DOE targets towards electrical characteristics. The electrical characteristics tests included interfacial contact resistance (ICR) that were performed to determine the effect of the optimization coating parameters after surface treatment. The best parameter was optimized through the tests performed that were analyzed by using the lowest $\mathrm{S} / \mathrm{N}$ ratio. ANOVA is performed to investigate the influence of gas flow rate, DC power and deposition time of coatings. The focus of this research is to achieve low interfacial contact resistance (ICR) so that high electrical conductivity in the PEMFC system, thereby increasing the corrosion resistance in the cathode cell. This will encourage the performance of the PEMFC stack is stable for both electrical conductivity and corrosion resistance based on U.S. DOE throughout the PEMFC operation cell.

\section{EXPERIMENTAL AND MATERIALS}

This study using SUS 316 L plates, in validation with the selected parameters (gas flow rate of 8 to $10 \mathrm{sccm}$, DC power of 80 to $100 \mathrm{~W}$ and deposition time of 60 to $80 \mathrm{~min}$ ) by applied coatings of $\mathrm{Nb}-\mathrm{C}$ and $\mathrm{Cr}-\mathrm{C}$ on the surface plate. The materials used was SUS $316 \mathrm{~L}$ with the chemical composition; Cr: 16\%; Ni: 10\%; Mo: $2 \%$; C: < 0.03\%; Mn: 1\%; Si: <0.75\%; P: <0.045\%; S: < 0.03\%; and Fe: Balance (in mass \%). It was chosen as metal plates preparation for the bipolar plates because it has been widely used in the commercial industry of PEMFC. SUS $316 \mathrm{~L}$ were cut into disk shaped (coupon) with a thickness of 3 $\mathrm{mm}$ were recommended. A lesser thickness will provide lightweight of material to sustain with reasonable strength for the bipolar plates (Yuan et al. 2005).

TF450 PVD magnetron sputtering system (SG Co. Ltd, Singapore) was equipped with commercially available 4 inches diameter by $3 \mathrm{~mm}$ thickness coating targets. The substrates were ultrasonically cleaned in acetone for $30 \mathrm{~min}$ to remove any contaminants from the surface metals, dried at room temperature before placing on the substrate holder in the PVD chamber. Inside the chamber, the substrate holder was placed onto a rotating stage to $20 \mathrm{rpm}$ that was connected to a resistive heater up to $180^{\circ} \mathrm{C}$. The PVD chamber is vacuum to $4.6 \times 10^{-6}$ Torr and pre-sputtering for $12 \mathrm{~h}$ using argon mixed with nitrogen before deposition process takes place. The heater onto the substrate begin during deposition and the working pressure is maintained to $1.4 \times 10^{-2}$ Torr.

\section{EXPERIMENTAL DESIGN AND DATA ANALYSIS}

The coating optimization parameters was conducted using Taguchi method for robust design without high amount of experimentation to be analysed (Bushroa et al. 2011). The control factors in experiment are gas flowrate ( $\mathrm{sccm}$ ), DC power (W) and deposition time ( $\mathrm{t}$ ) as shown in Table 1 , whereas each having two levels, high and low based on the previous experimentation and literature review (Wang et al. 2014; Zhao et al. 2016). In this work, an orthogonal array of $\mathrm{L}_{8}$ was utilized to study the effect of control factors (gas flow rate, DC power and deposition time) on the response to ICR and corrosion rate value in optimize the experimental error ( $\mathrm{S} / \mathrm{N}$ ratio) by the experimental design setting. Table 2 presents the observations table of $\mathrm{L}_{8}$ array obtained from parameters of each coating ( $\mathrm{Nb}-\mathrm{C}$ and $\mathrm{Cr}-\mathrm{C}$ ). The experiment conducted considers three factors (gas flow rate, DC power and deposition time) that will be varied to get the optimum parameters before starting the coating process. From the $\mathrm{L}_{8}$ orthogonal array, eight different designs of coating parameters are then simulated and go through for actual experimental by PVD coating. Each of the designed parameters will go through for the interfacial contact resistance test after coating. 
Researcher had claimed combination of statistical and engineering methods by applied Taguchi method was to determine the level of efficiency, validate experiments and help in reducing the cost of experiments conducted (Radzuan et al. 2016). In the meantime, calculating the signal to noise $(\mathrm{S} / \mathrm{N})$ ratio and a statistical analysis of variance (ANOVA) were carried out. Each parameter of control factors will be studied and determined as in prediction and actual experiment in validating the significant factors involved. In addition, contribution percentage of each parameter were studied via ANOVA accordance with interfacial contact resistance and corrosion resistance values. Variance analysis includes degree of freedom $(\mathrm{DF})$, variance $(\mathrm{V})$, ratio $(\mathrm{F})$, sum of square, pure sum and $\mathrm{P}-$ value (Oktiawati et al. 2017). In this work, the higher efficiency of interfacial contact resistance (ICR) represents better performance of SUS 316 L plates. Therefore, ICR studied with the concept of 'the smaller-the-better' was considered as the good quality characteristics SUS $316 \mathrm{~L}$ plates. The $\mathrm{S} / \mathrm{N}$ ratio for the smaller-the-better is as shown in (1);

$$
\mathrm{S} / \mathrm{N}=-10 \log \left|\frac{1}{n} \ldots \sum_{i=1}^{n} y_{i}{ }^{2}\right|
$$

By considering (1), the $\mathrm{S} / \mathrm{N}$ ratio values in this work are calculated, where $\mathrm{n}$ is the number of measurements in an experiment, whereas in this case, $n=1$ and $y$ is the measured efficiency value in an experiment.

TABLE 1. Factors sampling range

\begin{tabular}{lcc}
\hline \multicolumn{1}{c}{ Factors } & Level 1 & Level 2 \\
\hline Gas flow rate (sccm) & 8 & 10 \\
DC power (W) & 80 & 100 \\
Deposition time (t) & 60 & 80 \\
\hline
\end{tabular}

TABLE 2. Observations of Taguchi's model $\mathrm{L}_{8}$ orthogonal array of $\mathrm{Nb}-\mathrm{C}$ and $\mathrm{Cr}-\mathrm{C}$

\begin{tabular}{|c|c|c|c|}
\hline & A & $\mathrm{B}$ & $\mathrm{C}$ \\
\hline Exp. No. & $\begin{array}{c}\text { Gas flow rate } \\
\text { (sccm) }\end{array}$ & DC power $(\mathrm{W})$ & Deposition time ( $\mathrm{t}$ ) \\
\hline 1 & 1 & 1 & 1 \\
\hline 2 & 1 & 1 & 2 \\
\hline 3 & 1 & 2 & 1 \\
\hline 4 & 1 & 2 & 2 \\
\hline 5 & 2 & 1 & 1 \\
\hline 6 & 2 & 1 & 2 \\
\hline 7 & 2 & 2 & 1 \\
\hline 8 & 2 & 2 & 2 \\
\hline
\end{tabular}




\section{MEASUREMENT OF CORROSION RESISTANCE AND} INTERFACIAL CONTACT RESISTANCE

The corrosion resistance (CR) of SUS $316 \mathrm{~L}$ was analyzed using Tafel extrapolation by potentiostat PGZ100 (Voltalab 10). The procedure was controlled using Nova 1.10 electrochemical software. A flat cell of SUS 316 L was used as a coupon substrate at room temperature in a solution of $0.5 \mathrm{M}$ sulphuric acid $\left(\mathrm{H}_{2} \mathrm{SO}_{4}\right)$. The SUS 316 L substrate was used as the working electrode, the electrode of $\mathrm{Ag} / \mathrm{AgCl}$ was used as reference electrode, and platinum electrode acted as the counter electrode. All potentials were referred to the SCE during the experiment. The substrate was stabilized at open circuit (OCP) for 1 $\mathrm{h}$ and the data scan from the Tafel plotted were obtained under potential scan rate of $1 \mathrm{mV} / \mathrm{s}$. The corrosion current density (Icorr) aimed less than $1 \mu \mathrm{A} \mathrm{cm}^{-2}$.

The surface ICR of SUS $316 \mathrm{~L}$ plate after coating was measured by placing the plate between the carbon paper (as GDL) under the real simulation condition and by measuring the voltage drop as shown in (2), whereas $\mathrm{R}$ is the electrical contact resistance, $\mathrm{V}$ is the voltage drop through the setup, I is the applied current and $\mathrm{A}$ is the surface area.

$$
\begin{gathered}
(\mathrm{R}=\mathrm{VA} / \mathrm{I}) \\
(\mathrm{R} 1+\mathrm{R} 2 / 2)
\end{gathered}
$$

The ICR was equal to the total resistance in the test assembly as in (3), whereas R1 refers to the resistance of two copper plates, and $\mathrm{R} 2$ referred to the resistance of GDL with coated sample (R1 + R2/2). Requirements and testing method were applied based on through plane studied on ICR measurement (Jendras et al. 2017). It was performed using a customized through-plane electric flow device with $1 \mathrm{~A}$ of current supplied, at a pressure of $140 \mathrm{~N} \mathrm{~cm}^{-2}$, at operating temperature of $80{ }^{\circ} \mathrm{C}$.

\section{RESULTS AND DisCUSSION}

The orthogonal array of $\mathrm{L}_{8}$ obtained from the Taguchi method for two types of control factors, in order to study parameters of $\mathrm{Nb}-\mathrm{C}$ and $\mathrm{Cr}-\mathrm{C}$ coatings in each run of experimental. As in Table 3, the lowest ICR value $\left(1.1259 \mathrm{~m} \Omega . \mathrm{cm}^{2}\right)$ and corrosion rate $\left(137.71 \times 10^{-12} \mathrm{~A}\right)$ by $\mathrm{Nb}-\mathrm{C}$ coating were recorded on samples 7 and 4 , while sample 1 represents as the lowest ICR values (1.5595 $\left.\mathrm{m} \Omega . \mathrm{cm}^{2}\right)$ and corrosion rates $\left(70.1740 \times 10^{-12} \mathrm{~A}\right)$ as for $\mathrm{Cr}-\mathrm{C}$ coating. Hence, Table 4 only shows ICR values converted to $\mathrm{S} / \mathrm{N}$ ratio as the minimum response to the control factors. The smallest $\mathrm{S} / \mathrm{N}$ ratios for ICR of $\mathrm{Nb}-\mathrm{C}$ $(-4.86275 \mathrm{~dB})$ and $\mathrm{Cr}-\mathrm{C}(-7.9647 \mathrm{~dB})$ coating were found in samples 2 and 3 . Based on the $\mathrm{SN}$ ratio response, overall measures values for ICR gives minimize disturbances $(<10$ $\mathrm{m} \Omega . \mathrm{cm}^{2}$ ) with low $\mathrm{S} / \mathrm{N}$ ratio as the purpose of experimental design is to have less interference between parameters response (gas flow rate, DC power, and deposition time) (Utami et al. 2016).

\begin{tabular}{|c|c|c|c|c|c|}
\hline \multirow[b]{2}{*}{ Exp. No. } & ontrol Factors & \multicolumn{2}{|c|}{$\mathrm{Nb}-\mathrm{C}$} & \multicolumn{2}{|c|}{$\mathrm{Cr}-\mathrm{C}$} \\
\hline & Level & $\begin{array}{c}\text { ICR } \\
\left(\mathrm{m} \Omega . \mathrm{cm}^{2}\right)\end{array}$ & $\begin{array}{c}\mathrm{CR} \\
\left(\mathrm{A} / \mathrm{cm}^{2}\right)\end{array}$ & $\begin{array}{c}\mathrm{ICR} \\
\left(\mathrm{m} \Omega . \mathrm{cm}^{2}\right)\end{array}$ & $\begin{array}{c}\mathrm{CR} \\
\left(\mathrm{A} / \mathrm{cm}^{2}\right)\end{array}$ \\
\hline 1 & A1 B1 C1 & 1.5478 & $137.71 \times 10^{-12}$ & 1.5595 & $70.1740 \times 10^{-12}$ \\
\hline 2 & A1 B1 C2 & 1.7614 & $2.757 \times 10^{-9}$ & 2.0981 & $7.575 \times 10^{-9}$ \\
\hline 3 & A1 B2 C1 & 1.3766 & $1.982 \times 10^{-9}$ & 2.5017 & $2.513 \times 10^{-9}$ \\
\hline 4 & A1 B2 C2 & 1.2223 & $107.550 \times 10^{-12}$ & 2.2795 & $78.2870 \times 10^{-12}$ \\
\hline 5 & A2 B1 C1 & 1.6211 & $1.281 \times 10^{-9}$ & 1.7805 & $3.091 \times 10^{-9}$ \\
\hline 6 & A2 B1 C2 & 1.5248 & $1.736 \times 10^{-9}$ & 1.9591 & $86.431 \times 10^{-12}$ \\
\hline 7 & A2 B2 C1 & 1.1259 & $1.694 \times 10^{-9}$ & 1.8900 & $1.149 \times 10^{-9}$ \\
\hline 8 & A2 B2 C2 & 1.2559 & $1.597 \times 10^{-9}$ & 1.8805 & $3.928 \times 10^{-9}$ \\
\hline
\end{tabular}

TABLE 3. Measured values for ICR and corrosion rates of $\mathrm{Cr}-\mathrm{C}$ and $\mathrm{N}-\mathrm{C}$ in $\mathrm{L} 8$ array 
TABLE 4. Orthogonal array of Taguchi $\mathrm{L}_{8}$ indicates the value of ICR

\begin{tabular}{llcc}
\hline \multicolumn{2}{c}{ Factor } & ICR of Nb-C & ICR of Cr-C \\
Exp. No. & Parameter & \multicolumn{2}{c}{ S/N (dB) } \\
\hline 1 & A1 B1 C1 & -4.3037 & -4.6943 \\
2 & A1 B1 C2 & -4.8627 & -7.1499 \\
3 & A1 B2 C1 & -2.5076 & -7.9647 \\
4 & A1 B2 C2 & -1.9117 & -7.6967 \\
5 & A2 B1 C1 & -3.9604 & -5.9892 \\
6 & A2 B1 C2 & -4.0818 & -6.5952 \\
7 & A2 B2 C1 & -1.0638 & -5.4368 \\
8 & A2 B2 C2 & -1.4398 & -6.4058 \\
\hline
\end{tabular}

The interaction of $\mathrm{Nb}-\mathrm{C}$ between parameter of $\mathrm{A}, \mathrm{B}$, and $\mathrm{C}$ were analyzed with ANOVA, as in Table 5. The CR value does not affect the layer parameters used, because the contribution is less than $50 \%$. Therefore, only the ICR results were gone through the ANOVA, thus to determine the contribution percentages by each parameter used. In Table 5, B factor (DC power) contributes $89.54 \%$ and recorded as highest contribution towards ICR. However, A factor (gas flow rate) contributes $69.01 \%$ recorded by $\mathrm{Cr}-\mathrm{C}$ as shown in Table 6 . Toward a better understanding, DC power absorption along with temperature helps to react quickly in line with molecular enlargement and the pressure in the PVD chamber gives slight collision between molecule and gaseous (Yeldose et al. 2008). In addition, influenced of the parameter contribution on coating parameters to the ICR value are high, accordance with the optimal results obtained through the Taguchi method that has been carried out.

The ANOVA results also shows the relations impact of all factors by comparing the mean square with an approximation of the experimental errors at specific levels. The influence of $\mathrm{P}-$ value have a significant influence on the represents parameters. These impacts will statistically use to determine the implication of a factor. The same method used by many researchers in studies varied parameters with residual errors at specific levels (Oktiawati et al. 2017; Radzuan et al. 2016). The studied showed that the $\mathrm{P}$-value obtained must be in between 0.05 to confirm each optimization parameter carried out were significant (Ibrahim et al. 2010). From Tables 5 and 6, it observed that factors $\mathrm{A}$ and $\mathrm{B}$ influenced the most to $\mathrm{Nb}-\mathrm{C}$ coatings, while $\mathrm{Cr}-\mathrm{C}$ coatings only influenced by factor $\mathrm{A}$. It has been explained that $\mathrm{Nb}$ (niobium) element have low resistance material which can absorb the DC power along with temperature in molecular expansion, while $\mathrm{C}$ (carbon) atom provides rapid diffusion between substrate and $\mathrm{Nb}$ (Cai et al. 2016). The study also examined the mixture of nitrogen and argon gas in the PVD chamber will induces forming a coating and store more electrical energy as $\mathrm{Cr}$ (chromium) element known as high electrical conductivity (Yeldose et al. 2008).

TABLE 5. Orthogonal array of Taguchi $\mathrm{L}_{8}$ indicates the ICR value of $\mathrm{Nb}-\mathrm{C}$

\begin{tabular}{|c|c|c|c|c|c|c|}
\hline \multirow[b]{2}{*}{ Factor } & \multirow[b]{2}{*}{$\mathrm{DF}$} & \multicolumn{5}{|c|}{ ICR value of $\mathrm{Nb}-\mathrm{C}$} \\
\hline & & $\mathrm{S}$ & $\mathrm{V}$ & $\mathrm{F}$ & $\mathrm{P}$ & Contribution (\%) \\
\hline A & 1 & 0.029330 & 0.029330 & 10.98 & 0.03 & 7.46 \\
\hline B & 1 & 0.351877 & 0.351877 & 131.76 & 0.00 & 89.54 \\
\hline $\mathrm{C}$ & 1 & 0.001076 & 0.001076 & 0.40 & 0.56 & 0.27 \\
\hline Error & 4 & 0.010682 & 0.002671 & & & 2.72 \\
\hline Total & 7 & 0.392966 & & & & 100 \\
\hline
\end{tabular}


TABLE 6. Orthogonal array of Taguchi $\mathrm{L}_{8}$ indicates the ICR value of $\mathrm{Cr}-\mathrm{C}$

\begin{tabular}{|c|c|c|c|c|c|c|}
\hline \multirow{2}{*}{ Factor } & \multicolumn{6}{|c|}{ ICR value of $\mathrm{Cr}-\mathrm{C}$} \\
\hline & DF & $\mathrm{S}$ & $\mathrm{V}$ & $\mathrm{F}$ & $\mathrm{P}$ & Contribution (\%) \\
\hline A & 1 & 0.349281 & 0.349281 & 16.67 & 0.02 & 69.01 \\
\hline B & 1 & 0.072962 & 0.072962 & 3.48 & 0.14 & 14.42 \\
\hline $\mathrm{C}$ & 1 & 0.000012 & 0.000012 & 0.00 & 0.98 & 0.002 \\
\hline Error & 4 & 0.083813 & 0.020953 & & & 16.56 \\
\hline Total & 7 & 0.506067 & & & & 100 \\
\hline
\end{tabular}

Figure 1 shows the main effects plot of $\mathrm{S} / \mathrm{N}$ ratio with optimization parameter based on the lowest peak for each parameter $\mathrm{A}, \mathrm{B}$ and $\mathrm{C}$. The $\mathrm{S} / \mathrm{N}$ ratios in Table 3 were used to develop the main effects plot. Based on Figure 1(a) and 1(b), factor A and B are the most influenced parameters by the ICR in optimizing the coating parameters of $\mathrm{Nb}-\mathrm{C}$ and $\mathrm{Cr}-\mathrm{C}$. it has been seen in Figure 1(a), factor $\mathrm{A}$ (DC power) is the most influence parameter in optimizing the ICR values of the $\mathrm{Nb}-\mathrm{C}$ coating. It can be seen the graph pattern at $80 \mathrm{~W}$ of DC power and $8 \mathrm{sccm}$ of gas flow rate aligned parallel to the DC power to form coating onto $316 \mathrm{~L}$ substrate. Although the $\mathrm{Nb}$ (niobium) has poor electrical conductivity but it absorbs DC power along high temperature to react quickly in molecular expansion, while $\mathrm{C}$ (carbon) atoms give rapid infiltration of the substrate between the atoms $\mathrm{Nb}$ (Cai et al. 2016). In contrast, $\mathrm{Cr}-\mathrm{C}$ coating parameters further influenced by factor $\mathrm{B}$ (gas flow rate). Indeed, $\mathrm{Cr}$ (chromium) element has high electrical conductivity, but the mixture of nitrogen and argon gas induced to form the coating aligned in parallel with the deposition time as shown in Figure 1(b).

Nowadays, high corrosion resistance and good material performance of bipolar plates are very important in PEMFC aqueous acidic environment. Modification on the surface metal is needed to overcome this problem since it has certain life, which is prone to corrodes before physical damage occurs (Asri et al. 2017; Taherian 2014). It was an alternative method to slow down the corrosion process as $\mathrm{Nb}-\mathrm{C}$ (niobium carbide) and $\mathrm{Cr}-\mathrm{C}$ (chromium carbide) were suggested as coating on SUS $316 \mathrm{~L}$ plates. The best four performing parameters are defined in Table 3 for $\mathrm{CR}$ and ICR values of $\mathrm{Nb}-\mathrm{C}$ and $\mathrm{Cr}-\mathrm{C}$. According to Figure 2(a) and 2(b), the shape and position of the polarization curves affects by corrosion potential $\left(\mathrm{E}_{\text {corr }}\right)$ and samples had shown anodic reactions after been coated. Extrapolation of cathodic current density shows good in corrosion resistance. Table 7 presents the values of the corrosion potential $\left(\mathrm{E}_{\text {corr }}\right)$ and corrosion current density $\left(\mathrm{I}_{\text {corr }}\right)$ for each coating parameters selected in polarization conditions. The highest $\mathrm{E}_{\text {corr }}$ for $\mathrm{Nb}-\mathrm{C}$ and $\mathrm{Cr}-\mathrm{C}$ are -11 and $-106 \mathrm{~V}$, that presented by samples 8 and 1 . It can be observed that by increasing the $\mathrm{E}_{\text {corr }}$ value, the $\mathrm{I}_{\text {corr }}$ value will decrease and potentially reduce the corrosion attack after coatings. However, $\mathrm{Nb}-\mathrm{C} 4$ is chosen based on the lowest $\mathrm{I}_{\text {corr }}$ presents with good ICR among other parameters.

TABLE 7. The values of and $\mathrm{E}_{\text {corr }}$ and $\mathrm{I}_{\text {corr }}$ for SUS $316 \mathrm{~L}$ plates with $\mathrm{Nb}-\mathrm{C}$ and $\mathrm{Cr}-\mathrm{C}$ coatings in polarization conditions

\begin{tabular}{lccccc}
\hline \multicolumn{1}{c}{ Material } & \multicolumn{2}{c}{$\mathrm{Nb}-\mathrm{C}$} & Material & \multicolumn{2}{c}{ Cr-C } \\
\hline Sample & $\begin{array}{c}\mathrm{E}_{\text {corr }} \\
(\mathrm{mV})\end{array}$ & $\begin{array}{c}\mathrm{I}_{\text {corr }} \\
\left(\mathrm{A} / \mathrm{cm}^{2}\right)\end{array}$ & Sample & $\begin{array}{c}\mathrm{E}_{\text {corr }} \\
(\mathrm{V})\end{array}$ & $\begin{array}{c}\mathrm{I}_{\text {corr }} \\
\left(\mathrm{A} / \mathrm{cm}^{2}\right)\end{array}$ \\
\hline $316 \mathrm{~L}$ & -709 & $1.75430 \times 10^{-9}$ & $316 \mathrm{~L}$ & -709 & $1.75430 \times 10^{-9}$ \\
1 & -31 & $137.71 \times 10^{-12}$ & 1 & -106 & $70.1740 \times 10^{-12}$ \\
4 & -78 & $107.550 \times 10^{-12}$ & 4 & -139 & $78.2870 \times 10^{-12}$ \\
5 & -232 & $1.281 \times 10^{-9}$ & 6 & -387 & $86.431 \times 10^{-12}$ \\
8 & -11 & $1.597 \times 10^{-9}$ & 7 & -300 & $1.149 \times 10^{-9}$ \\
\hline
\end{tabular}


Figure 3 exhibits the ICR values measured at temperatures of $40,60,80$, and $100{ }^{\circ} \mathrm{C}$ for the four best parameters. It can be seen the ICR values of SUS 316 $\mathrm{L}\left(4.6307 \mathrm{~m} \Omega \mathrm{cm}^{2}\right.$ to $2.6358 \mathrm{~m} \Omega \mathrm{cm}^{2}$ at 40 to $\left.100{ }^{\circ} \mathrm{C}\right)$ decreased with the increase of temperature from 40 to 100 ${ }^{\circ} \mathrm{C}$ after $\mathrm{Nb}-\mathrm{C}$ and $\mathrm{Cr}-\mathrm{C}$ coatings. As in Figure 3(a), the ICR results after $\mathrm{Nb}-\mathrm{C}$ coatings showed the performance of the samples from the lowest value in order of $\mathrm{Nb}-\mathrm{C} 7<$ $\mathrm{Nb}-\mathrm{C} 4<\mathrm{Nb}-\mathrm{C} 8<\mathrm{Nb}-\mathrm{C} 3<\mathrm{SUS} 316 \mathrm{~L}$. Whereas, the ICR for $\mathrm{Cr}-\mathrm{C}$ coatings are $\mathrm{Cr}-\mathrm{C} 1<\mathrm{Cr}-\mathrm{C} 5<\mathrm{Cr}-\mathrm{C} 8<$ $\mathrm{Cr}-\mathrm{C} 6<$ SUS $316 \mathrm{~L}$ as seen in Figure 3(b). Overall, the ICR values for SUS $316 \mathrm{~L}$ plates after coatings meets the requirement of U.S DOE, less than $10 \mathrm{~m} \Omega \mathrm{cm}^{2}$.
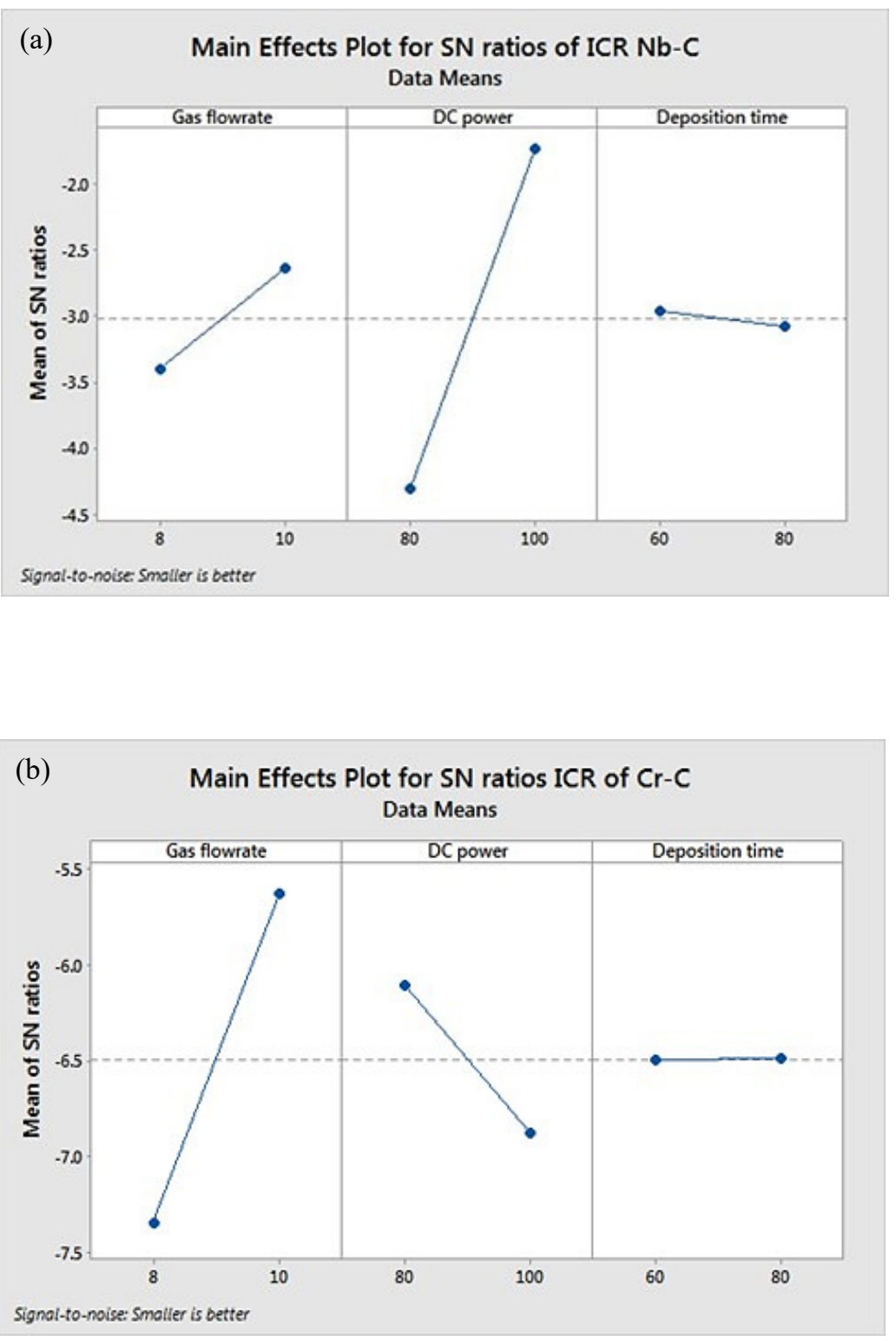

FIGURE 1. The main effects plot for $\mathrm{S} / \mathrm{N}$ ratios of (a) ICR for $\mathrm{Nb}-\mathrm{C}$ coating and (b) ICR for $\mathrm{Cr}-\mathrm{C}$ coating 

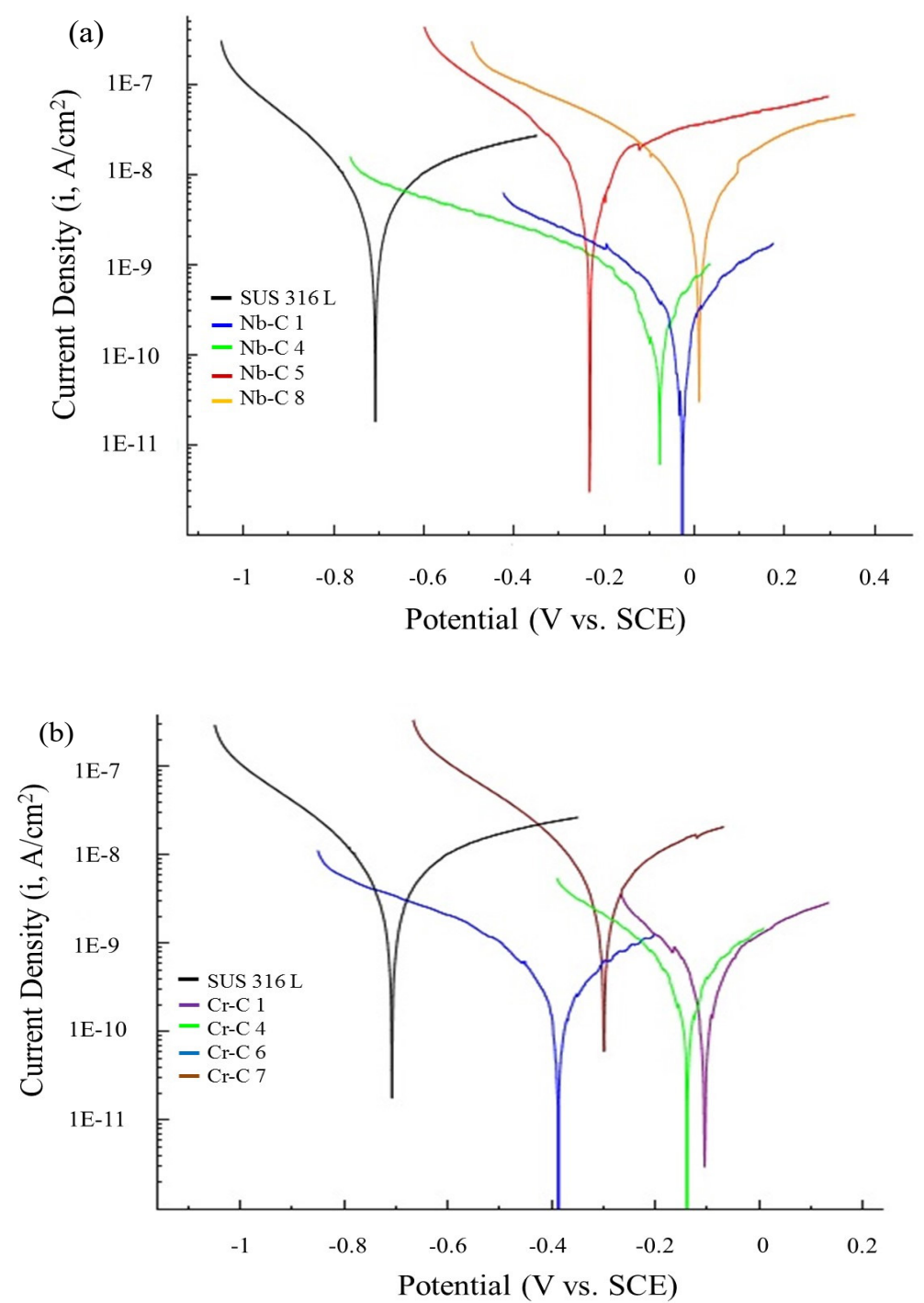

FIGURE 2. Polarization curves of Tafel plots of (a) $\mathrm{Nb}-\mathrm{C}$ and (b) $\mathrm{Cr}-\mathrm{C}$ coatings with different parameters

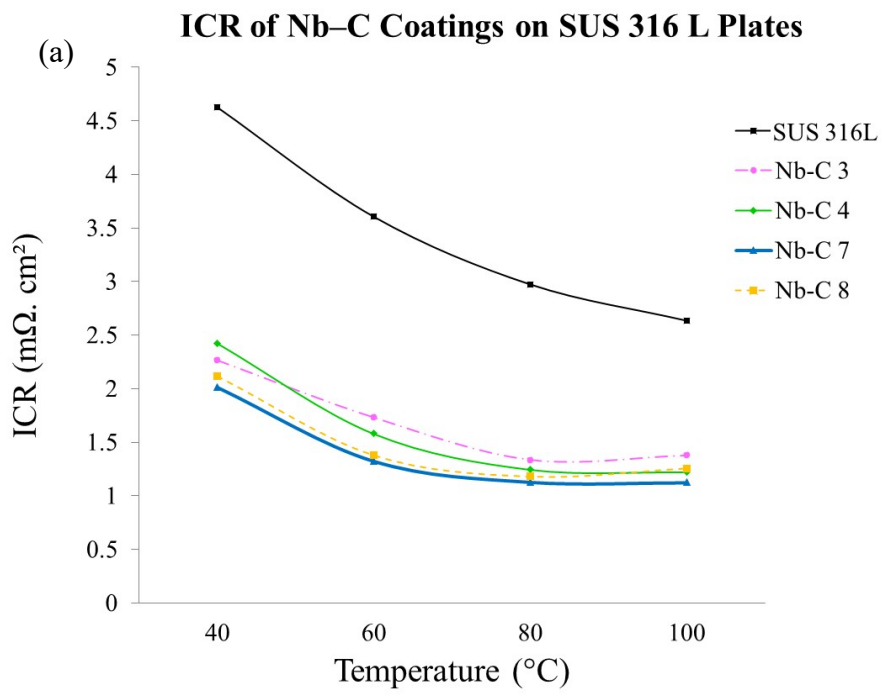




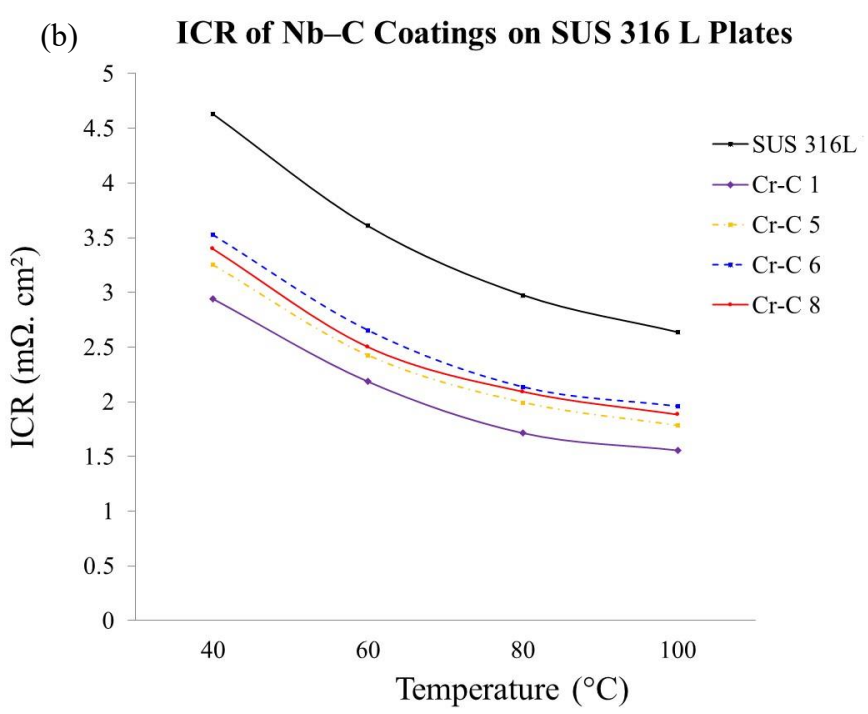

FIGURE 3. ICR values before and after coatings of (a) $\mathrm{Nb}-\mathrm{C}$ and (b) $\mathrm{Cr}-\mathrm{C}$ with different parameters

\section{CONCLUSION}

In this study, an orthogonal Taguchi $\mathrm{L}_{8}$ array was used to investigate the effects of the synthesis parameters on $\mathrm{Nb}-\mathrm{C}$ and $\mathrm{Cr}-\mathrm{C}$ coatings using PVD coating method. The parameters studied is used to optimize the coating process as well as to improve corrosion behavior and interfacial contact resistance on SUS $316 \mathrm{~L}$ plates. Optimization of coating parameters are selected for sample $\mathrm{Nb}-\mathrm{C} 4(8$ sccm, $100 \mathrm{~W}$ and $80 \mathrm{~min}$ ) and $\mathrm{Cr}-\mathrm{C} 1$ (8 sccm, $80 \mathrm{~W}$ and $60 \mathrm{~min})$, in relation with lowest current density ( $\left.\mathrm{I}_{\text {corr }}\right)$ and ICR values. In addition, the study found the DC power $(89.54 \%)$ and the gas flow rate $(69.01 \%)$ gives high percentages contribution to the ICR values of $\mathrm{Nb}-\mathrm{C}$ and $\mathrm{Cr}-\mathrm{C}$ after coating. The test results are statistically significantly with the $\mathrm{P}-$ value $\leq 0.05$. Moreover, SUS 316 L had achieved the standard of U.S. DOE technical target in $\mathrm{I}_{\text {corr }}\left(\leq 1 \mu \mathrm{A} / \mathrm{cm}^{2}\right)$ and ICR $\left(\leq 10 \mathrm{~m} \Omega . \mathrm{cm}^{2}\right)$ as a bipolar plate potential in PEMFC.

\section{ACKNOWLEDGEMENTS}

The research was financially supported by the grant of Universiti Kebangsaan Malaysia INOVASI-2019-002 and the Ministry of Education, Malaysia Research Grant FRGS/1/2017/TK10/UKM/02/6 and gratefully acknowledged everyone who collaborated including Fuel Cell Institute UKM.

\section{REFERENCES}

Arwati, I.G.A., Majlan, E.H., Shyuan, L.K., Arifin, K., Husaini, T., Alva, S. \& Radzuan, N.A.M. 2019. Kesan pemendapan elektroforesis gam arab terhadap halaju kakisan pada aluminium 5052. Sains Malaysiana 48(2): 401-406.

Asri, N.F., Husaini, T., Sulong, A.B., Majlan, E.H. \& Daud, W.R.W. 2017. Coating of stainless steel and titanium bipolar plates for anticorrosion in PEMFC: A review. International Journal of Hydrogen Energy 42(14): $9135-$ 9148.

Baroutaji, A., Carton, J.G., Sajjia, M. \& Olabi, A.G. 2015. Materials in PEM fuel Cells. In Materials Science and Materials Engineering. Amsterdam: Elsevier pp. 1-30.

Bushroa, A.R., Masjuki, H.H. \& Muhamad, M.R. 2011. Parameter optimization of sputtered $\mathrm{Ti}$ interlayer using Taguchi method. International Journal of Mechanical and Materials Engineering 6(2): 140-146.

Cai, X., Xu, Y., Zhao, N., Zhong, L., Zhao, Z. \& Wang, J. 2016. Investigation of the adhesion strength and deformation behaviour of in situ fabricated $\mathrm{NbC}$ coatings by scratch testing. Surface and Coatings Technology 299: 135-142.

Hartnig, C. \& Schmidt, T.J. 2011. On a new degradation mode for high temperature polymer electrolyte fuel cells: How bipolar plate degradation affects cell performance. Electrochimica Acta 56(11): 4237-4242.

Huang, N.B., Yu, H., Xu, L.S., Zhan, S., Sun, M. \& Kirk, D.W. 2016. Corrosion kinetics of $316 \mathrm{~L}$ stainless steel bipolar plate with chromium carbide coating in simulated PEMFC in cathodic environment. Result in Physics 6: 730-736.

Ibrahim, M.H.I., Muhamad, N., Sulong, A.B., Jamaludin, K.R., Nor, N.H.M. \& Ahmad, S. 2011. Optimization of micro metal injection molding SS 316L for the highest green strength by using Taguchi method. Advanced Materials Research 264265: 135-140.

Jendras, P., Lötsch, K. \& Unwerth, T. 2017. Requirements and testing methods for surfaces of metallic bipolar plates for 
low temperature PEM fuel cells. In IOP Conference Series: Materials Science and Engineering 181(1): 1-6.

Li, W., Ming-hui, D., Hong-sen, Z. \& Bin, Z. 2018. Study on HfCxN1-x coatings deposited on biomedical AISI 316 L by radio-frequency magnetron sputtering. Journal of Alloys and Compounds 730: 219-227.

Madadi, F., Rezaeian, A., Edris, H. \& Zhiani, M. 2019. Improving performance in PEMFC by applying different coatings to metallic bipolar plates. Materials Chemistry and Physics 238(3): 121911

Oktiawati, U.Y., Mohamed, N.M. \& Burhanudin, Z.A. 2017. Applications of Taguchi method for optimization of dye solar cell design. Sains Malaysiana 46(3): 503-508.

Mani, S.P. \& Rajendran, N. 2017. Corrosion and interfacial contact resistance behavior of electrochemically nitrided 316 L SS bipolar plates for proton exchange membrane fuel cells. Energy 133: 1050-1062.

Radzuan, N.A.M., Sulong, A.B. \& Somalu, M.R. 2016. Pengoptimuman proses penyemperitan gentian karbon terkisar dan polipropilena bagi komposit polimer pengalir. Sains Malaysiana 45(12): 1913-1921.

Taherian, R. 2014. A review of composite and metallic bipolar plates in proton exchange membrane fuel cell: Materials, fabrication, and material selection. Journal of Power Sources 265: 370-390.

Utami, R.S., Puspasari, I., Shyuan, L.K., Mohamed, A.B. \& Alva, S. 2016. Effect of process parameters on the synthesis of polypyrrole by the Taguchi method. Malaysian Journal of Analytical Sciences 20(3): 660-669.

Wang, H., Sweikart, M.A. \& Turner, J.A. 2003. Stainless steel as bipolar plate material for polymer electrolyte membrane fuel cells. Journal of Power Sources 115(2): 243-251.

Wang, L., Sun, J., Kang, B., Li, S., Ji, S., Wen, Z. \& Wang, X. 2014. Electrochemical behaviour and surface conductivity of niobium carbide modified austenitic stainless steel bipolar plate. Journal of Power Sources 246: 775-782.
Wang, Y., Zhang, S., Lu, Z., Wang, L. \& Li, W. 2018. Preparation and performances of electrically conductive $\mathrm{Nb}$-doped $\mathrm{TiO}_{2}$ coatings for 316 stainless steel bipolar plates of proton exchange membrane fuel cells. RSC Advances 142: 249-257.

Yang, L., Qin, Z., Pan, H., Yun, H., Min, Y. \& Xu, Q. 2017 Corrosion protection of 304 stainless steel bipolar plates of PEMFC by coating $\mathrm{SnO}$ film. International Journal of Electrochemical Science 12: 10946-10957.

Yeldose, B.C. \& Ramamoorthy, B. 2007. Characterization of de magnetron sputtered diamond-like carbon (DLC) nano coating. The International Journal of Advanced Manufacturing Technology 38(7-8): 705-717.

Yuan, X.Z., Wang, H., Zhang, J. \& Wilkinson, D.P. 2005. Bipolar plates for PEM fuel cells-fFrom materials to processing. Journal of New Materials for Electrochemical Systems 8(4): 257-267.

Zhao, Y., Wei, L., Yi, P. \& Peng, L. 2016. Influence of Cr-C film composition on electrical and corrosion properties of $316 \mathrm{~L}$ stainless steel as bipolar plates for PEMFCs. International Journal of Hydrogen Energy 41(2): 1142-1150.

Nur Fawwaz Asri, Teuku Husaini* \& Edy Herianto Majlan Fuel Cell Institute

Universiti Kebangsaan Malaysia

43600 UKM Bangi, Selangor Darul Ehsan

Malaysia

Abu Bakar Sulong

Centre for Materials Engineering and Smart Manufacturing

Faculty of Engineering and Built Environment

Universiti Kebangsaan Malaysia

43600 UKM Bangi, Selangor Darul Ehsan

Malaysia

*Corresponding author; email: t-husaini@ukm.edu.my

Received: 4 August 2020

Accepted: 11 September 2020 